\title{
Electrotonic Coupling in the Pituitary Supports the Hypothalamic-Pituitary-Gonadal Axis in a Sex Specific Manner
}

\section{OPEN ACCESS}

Edited by:

Jean-Marc Taymans,

French Institute of Health and Medical

Research, France

Reviewed by:

David Ruskin,

Trinity College, USA

Patrick E. Chappell,

Oregon State University, USA

*Correspondence:

Hannah Monyer

h.monyer@dkfz-heidelberg.de

${ }^{\dagger}$ Present Address:

Christina Göngrich,

Department of Neuroscience, Karolinska Institute, Stockholm,

Sweden;

Corentin Le Magueresse, Institut du Fer à Moulin, Institut

National de la Santé et de la Recherche Médicale UMR-S 839 and Université Pierre et Marie Curie, Paris,

France

${ }^{\ddagger}$ These authors have contributed equally to this work.

Received: 19 April 2016

Accepted: 21 July 2016

Published: 18 August 2016

Citation: Göngrich C, García-González D, Le Magueresse $C$, Roth LC, Watanabe $Y$, Burks DJ, Grinevich V and Monyer $H$ (2016) Electrotonic Coupling in the Pituitary Supports the Hypothalamic-Pituitary-Gonadal Axis in a Sex Specific Manner.

Front. Mol. Neurosci. 9:65. doi: 10.3389/fnmol.2016.00065

\section{Christina Göngrich ${ }^{1+\neq}$, Diego García-González ${ }^{1 \neq}$, Corentin Le Magueresse ${ }^{1 \dagger}$, Lena C. Roth ${ }^{2}$, Yasuhito Watanabe ${ }^{1}$, Deborah J. Burks ${ }^{3}$, Valery Grinevich ${ }^{2,4 \neq}$ and Hannah Monyer ${ }^{1 * \neq}$}

${ }^{1}$ Department of Clinical Neurobiology, Medical Faculty of Heidelberg, German Cancer Research Center, University of Heidelberg, Heidelberg, Germany, ${ }^{2}$ Schaller Research Group on Neuropeptides, German Cancer Research Center, CellNetwork Cluster of Excellence, University of Heidelberg, Heidelberg, Germany, ${ }^{3}$ Laboratory of Molecular Endocrinology, Centro de Investigación Príncipe Felipe, Valencia, Spain, ${ }^{4}$ Central Institute of Mental Health, Mannheim, Germany

Gap junctions are present in many cell types throughout the animal kingdom and allow fast intercellular electrical and chemical communication between neighboring cells. Connexin-36 (Cx36), the major neuronal gap junction protein, synchronizes cellular activity in the brain, but also in other organs. Here we identify a sex-specific role for Cx36 within the hypothalamic-pituitary-gonadal (HPG) axis at the level of the anterior pituitary gland (AP). We show that Cx36 is expressed in gonadotropes of the AP sustaining their synchronous activity. Cx36 ablation affects the entire downstream HPG axis in females, but not in males. We demonstrate that Cx36-mediated coupling between gonadotropes in the AP supports gonadotropin-releasing hormone-induced secretion of luteinizing hormone. Furthermore, we provide evidence for negative feedback regulation of Cx36 expression in the AP by estradiol. We thus, conclude that hormonally-controlled plasticity of gap junction communication at the level of the AP constitutes an additional mechanism affecting female reproduction.

Keywords: gap junctions, hypothalamus, pituitary gland, reproduction, sex specificity

\section{INTRODUCTION}

In vertebrates, gap junctions are formed by the connexin protein family, which consists of 20 isoforms in mice (Bennett and Zukin, 2004; Söhl et al., 2005). Connexin-36 (Cx36) is the major neuronal connexin isoform in rodents. In contrast to most other connexins, it forms exclusively homomeric and homotypic channels interconnecting selectively specific neuronal subtypes in many brain areas, including hippocampus, neocortex, reticular thalamus, olfactory bulb, and cerebellum (Al-Ubaidi et al., 2000; Belluardo et al., 2000; Deans et al., 2001; Hormuzdi et al., 2001; Long et al., 2002). In peripheral tissues Cx36 regulates insulin secretion from pancreatic ß-cells and catecholamine release from the adrenal medulla (Serre-Beinier et al., 2000; Martin et al., 2001; Ravier et al., 2005; Desarmenien et al., 2013). It is further expressed in the anterior pituitary (AP) gland, however, neither a function nor the cell type expressing $\mathrm{Cx} 36$ have been identified (Belluardo et al., 2000).

Episodic secretion of gonadotropin-releasing hormone (GnRH) from hypothalamic GnRH neurons elicits increases of $\left[\mathrm{Ca}^{2+}\right]_{i}$ in gonadotropes leading to the pulsatile release of luteinizing 
hormone (LH) and follicle-stimulating hormone (FSH; Baird, 1978; Belchetz et al., 1978; Wildt et al., 1981; Tse et al., 1993). The mechanism of synchronous GnRH release from the median eminence has been much studied and includes both intrinsic and extrinsic factors. For instance, GnRH neurons are connected via the so-called "dendrons," i.e., contacts serving both as dendrites and axons that support synchronous activity (Campbell et al., 2009). Of the external neuromodulators, kisspeptin neurons in the hypothalamic arcuate nucleus merit special mentioning (Yip et al., 2015). They are electrically coupled by Cx36-containing gap junctions (Campbell et al., 2011), and ablation of the kisspeptin gene prevents pulsatile LH release (Uenoyama et al., 2015). Conversely, optogenetic stimulation of kisspeptin neuron terminals induces pulsatile LH release in mice (Han et al., 2015).

Downstream of the pituitary, LH and FSH control the maturation of ovarian follicles, estradiol secretion, and ovulation in females (Wang and Greenwald, 1993). Whilst the pulsatile nature of gonadotropin secretion is controlled by $\mathrm{GnRH}$, the frequency and amplitude are modulated by gonadal steroids (Belchetz et al., 1978; Leipheimer et al., 1984). However, it is not known whether additional local processes at the level of the AP itself may contribute to the fine-tuning and synchronization of gonadotrope activity that is necessary to generate the sharp LH and FSH pulses known to be present in the circulation. The presence of gap junctions in the AP between somatotropes, lactotropes, and folliculo-stellate cells has been evidenced by pharmacological and physiological studies (Guérineau et al., 1998; Fauquier et al., 2001; Hodson et al., 2012). A similar local mechanism for gonadotropes can be inferred from an in vitro study in which the authors demonstrated persistent rhythmic secretion of LH from an isolated pituitary (Gambacciani et al., 1987).

In this study we demonstrate the presence of gap junctions between gonadotropes, report reduced fertility in $\mathrm{C} \times 36^{-/-}$ females, and show decreased LH secretion as a result of impaired gap junctional coupling between gonadotropes in the AP. Furthermore, we identify a negative feedback on $\mathrm{Cx} 36$ expression, exerted by ovary-derived estradiol.

\section{MATERIALS AND METHODS}

All mice were housed at the standard animal facility in polypropylene macrolon cages with food and water ad libitum (12 h light-dark cycle 7 a.m. -7 p.m., temperature at $20 \pm 1^{\circ} \mathrm{C}$, humidity $50 \pm 10 \%)$. Unless otherwise indicated, the mice were between 5 and 6 months old at the start of the experiments. All animal tests were approved by the ethics committee of the Regierungspräsidium Karlsruhe (Germany). The experimenter was unaware of the genotype.

\section{Fertility and Puberty Analyses}

Eight to nine week old virgin females were mated with wt males for 10 days. For each mating pair the success of mating was scored, the time until the female littered down was measured and the number of pups per litter was counted. To determine puberty onset female mice were observed daily for vaginal opening starting at P22. Vaginal opening was further confirmed in the following days.

\section{Estrus Cycle Analysis and Hormone Measurements}

Prior to hormone measurements, the cycle stage of 5 to 7 months old females was determined by analysis of cytological changes in the vaginal epithelium. Mice were handled for 2 weeks, and vaginal smears were taken daily at $3 \pm 1 \mathrm{~h}$ after lights-on. The cells were stained according to Papanicolaou's protocol (Papanicolaou, 1942) and cell populations were counted using a light microscope. Two to six consecutive estrous cycles were analyzed per female. For estradiol measurement serum was prepared from trunk blood of wt and $\mathrm{C} \times 36^{-/-}$female mice that were sacrificed in the afternoon of the first day of estrus. Estradiol concentration was measured by HPLC.

\section{Plasma LH Measurements}

Six to seven months old male mice and female mice at the stage of estrus in the morning were sacrificed with $\mathrm{CO}_{2}$, and the blood was taken from the vena cava inferior into EDTAcontaining syringes. The blood was collected on ice in EDTAcoated tubes (BD Mictrotainer ${ }^{\mathrm{TM}}$, Becton, Dickinson \& Co, USA) and centrifuged $20 \mathrm{~min}$ at $4^{\circ} \mathrm{C}, 2000 \mathrm{rpm}$. Plasma was stored in Eppendorf tubes at $-80^{\circ} \mathrm{C}$. Mouse $\mathrm{LH}$ radioimmunoassay (RIA) was performed by the Endocrine Technology and Support Lab, Oregon National Primate Research Center (Beaverton, OR) using a traditional double-antibody RIA procedure similar to that described previously (Pau et al., 1986). The LH RIA kit was purchased from Dr. Albert Parlow (NHPP, HarborUCLA Medical Center, Los Angeles). The detection limit of the assay was $0.01953 \mathrm{ng} / \mathrm{tube}$ (i.e., $0.2 \mathrm{ng} / \mathrm{ml}$ ). A mouse serum pool was used in triplicate in each assay as quality control. The interassay variation is estimated at $14.7 \%$ ( $n=5$ assays) and the intra-assay variation in those 5 assays averaged 3.83\% $(0.4-7.8 \%)$.

\section{Plasma Testosterone ( $\mathrm{T}$ ) Measurements}

Male mice were sacrificed with $\mathrm{CO}_{2}$ and samples $(2 \mu \mathrm{l})$ were extracted in $5 \mathrm{ml}$ ether in $13 \mathrm{X} 100$ glass tubes (baked at $500^{\circ} \mathrm{C}$ for $30 \mathrm{~min}$ ), dried under forced air, and analyzed by specific T RIA. Hormonal values were corrected for extraction losses determined by radioactive trace recovery at the same time with sample extraction; hot recovery usually is better than $90 \%$. The sensitivity was $5 \mathrm{pg} /$ tube for the T RIA. The intra-assay variation was $5.1 \%$ for the $\mathrm{T}$ assay. Experiments were performed at the Endocrine Technology and Support Core Lab (ETSL) at the Oregon National Primate Research Center/Oregon Health \& Science University (Rasmussen et al., 1984).

\section{Haematoxylin-Eosin Staining of Ovaries}

After embedding in paraffin, serial $5 \mu \mathrm{m}$ sections were prepared for H\&E staining and quantification. Sections were deparaffinized and stained as described previously (Burks et al., 2000). Area and diameter measurements were carried out with ImageJ software (NIH). Representative images were obtained from $20 \mu \mathrm{m}$ cryostat sections. 
Estradiol measurements and analysis of ovarian morphology was statistically analyzed using Sigma Plot. For the remaining experiments the SPSS 16.0 software was used.

\section{Tissue Preparation for Histochemistry}

Mice were deeply anesthetized by intraperitoneal injection of ketamine/xylazine, transcardially perfused, and the tissue was post-fixed with $4 \%$ parafomaldehyde (PFA) in PBS ( $\mathrm{pH} 7.4$ ). Pituitaries and brains were sectioned coronally using a Leica VT1000S vibratome (Leica, Germany). Ovaries were dissected from wt and $\mathrm{C} \times 36^{-/-}$females in the afternoon of the first day of estrus and fixed in 4\% PFA.

\section{Immunohistochemistry}

Free-floating sections were permeabilized with $0.2 \%$ TritonX100 and blocked in 5\% BSA prior to antibody incubation. Primary antibody incubation was carried out for $18-48 \mathrm{~h}$ at $4^{\circ} \mathrm{C}$, secondary antibody incubation was carried out at room temperature (RT) for $2 \mathrm{~h}$. Antibodies were chicken anti-EGFP (1:500, Abcam, ab13970), rabbit anti-LHRH (LR1; 1:3000, gift from Dr. R. Benoit, McGill University, Montreal, Canada), rabbit anti mouse-LH (1:2000, mybiosource.com, MBS220981), rabbit anti-mouse FSH (1:1000, Dr. A.F. Parlow, National Hormone and Pituitary Program, NIH) Secondary antibodies: anti-rabbit Alexa 488, anti-rabbit Alexa 555, anti-chicken Alexa 488 (1:1000, Invitrogen), anti-rabbit Cy3 (1:2000, Dianova), anti-chicken FITC, and anti-rabbit Cy3 (1:500; Jackson ImmunoResearch Laboratories, Inc.). Cells were counted using the cell counter plug-in in NIH ImageJ v1.48a.

\section{In situ Hybridization Combined with Immunohistochemistry}

Five months old female wt and Cx $36^{-/-}$mice were deeply anesthetized, and transcardially perfused with PBS for $2 \mathrm{~min}$, followed by $4 \%$ PFA for $30 \mathrm{~min}$, 5\% glycerol with $0.5 \%$ Dimethylsulfoxid (DMSO) in PBS for $5 \mathrm{~min}$, and 20\% glycerol with $2 \%$ DMSO in PBS for $30 \mathrm{~min}$. To minimize RNA degradation, protectRNA (Sigma-Aldrich) was added to 4\% PFA and glycerol. Pituitaries were removed, frozen on dry ice, and kept at $-80^{\circ} \mathrm{C}$ until use. Eighteen micrometer cryosections of the pituitary were prepared and attached to the same microscope slides. Sections were dried at room temperature (RT) for $30 \mathrm{~min}$ before performing in situ hybridization using a viewRNA ISH Tissue 2-Plex Assay kit and the viewRNA Typel probe against mouse Cx36 (\#VB1-18818, Affymetrix, UK). In situ hybridization was performed following the protocol of the manufacturer. In brief, sections were treated with protease for $10 \mathrm{~min}$ at $40^{\circ} \mathrm{C}$, hybridized with the probe, and the probe was colorized. After in situ hybridization, sections were treated with a blocking solution (1\% BSA and $0.2 \%$ TritonX-100 in PBS) for $1 \mathrm{~h}$, and incubated with rabbit anti-rat LH beta (1:400, \#AFP571292393, Dr. A. F. Parlow, National Hormone \& Peptide Program, California) diluted in $0.2 \%$ TritonX-100 in PBS overnight at $4^{\circ} \mathrm{C}$. Sections were washed with PBS and incubated with secondary antibody (1:500, donkey anti-rabbit IgG, Alexa Fluor 647 conjugate, A31573, Thermo Fisher Scientific) for $2 \mathrm{~h}$ at RT. After washing with PBS, sections were counterstained with DAPI (1:500) diluted in water for $30 \mathrm{~min}$ at RT. Sections were washed again with PBS, airdried for $20 \mathrm{~min}$ at RT and coverslipped using Fluoromount-G (00-4958-02, eBioscience, Germany).

\section{Electrophysiology}

Pituitary sections were prepared from juvenile Cx36-EGFP mice (3-7 weeks). Mice were deeply anesthetized and killed by decapitation. The pituitary gland was removed and embedded in $2 \%$ Agar. Two-hundred and fifty micrometers thick coronal slices were cut using a vibratome (HR2, Sigmann Elektronik) in ice-cold ACSF containing (in $\mathrm{mM}$ ): $120 \mathrm{NaCl}, 3.5 \mathrm{KCl}, 2.5$ $\mathrm{CaCl}_{2}, 1.3 \mathrm{MgSO} 4,1.25 \mathrm{NaH}_{2} \mathrm{PO}_{4}, 25 \mathrm{NaHCO}_{3}, 25$ glucose $(\mathrm{pH}$ 7.2). Whole-cell current clamp recordings were made at 30$32^{\circ} \mathrm{C}$ from visually identified EGFP-positive cells using an EPC8 amplifier (HEKA) and a confocal upright microscope (TCS SP5, Leica) equipped with IR-DIC and standard epifluorescence. Patch pipettes had a resistance of 4-6 M $\Omega$ when filled with (in $\mathrm{mM}$ ): $105 \mathrm{Kgluconate}, 30 \mathrm{KCl}, 4 \mathrm{Mg}$-ATP, 10 phosphocreatine, $0.3 \mathrm{GTP}$, and 10 HEPES, adjusted to $\mathrm{pH} 7.3$ with $\mathrm{KOH}$ (final osmolarity $\sim 290 \mathrm{mOsm}$ ). Sulforhodamine (final concentration $20 \mu \mathrm{M}$ ) was routinely added to the intracellular solution. Cells were held at $-60 \mathrm{mV}$. Signals were acquired using two EPC8 amplifiers and PatchMaster software (HEKA), sampled at $20 \mathrm{kHz}$, filtered at $3 \mathrm{kHz}$, and analyzed using IgorPro (Wavemetrics). The coupling coefficient was calculated as the ratio of the voltage response in cell 2 divided by the voltage response in cell 1 under steady-state conditions. It was obtained by averaging 10 to 60 consecutive sweeps. Data are presented as mean \pm standard error of the mean (SEM).

\section{Calcium Imaging}

To rule out possible variations due to fluctuating expression levels of GnRH-R, Cx36, and hormones during the estrous cycle, mice were staged based on the cytological examination of the vaginal smear each day at the same time and 8-12 week old female wild-type and $\mathrm{C} \times 36^{-/-}$mice were sacrificed when they were in estrus. After decapitation under isofluorane anesthesia, the pituitary gland was carefully dissected out and embedded in $2 \%$ agarose (Applichem) in ACSF at $37^{\circ} \mathrm{C}$. The slicing chamber was filled with ACSF and coronal slices ( $150 \mu \mathrm{m}$ thick) were obtained using a vibratome (HR2, Sigmann Elektronik). Slices were immediately transferred to an incubator plate with ACSF under continuous bubbling at RT. Subsequently, slices were incubated in a solution containing the cell-permeable fluorescent $\mathrm{Ca}^{2+}$ indicator Fluo-4 AM (5 $\mu \mathrm{M}$; Invitrogen), Cell Tracker Red CMTPX (10 $\mu \mathrm{M}$; Invitrogen) to delineate cell membranes and pluronic F127 (0.02\%; Invitrogen). Dye loading was carried out at RT for $40-45 \mathrm{~min}$.

Imaging of fluorescently labeled cells in acute slices was performed on a TCS SP5 microscope (Leica) equipped with a $20 \mathrm{x}$ (1 numerical aperture) water-immersion objective. Images $(512 \times 512$ pixels $)$ were acquired at $1000 \mathrm{~Hz}$ speed every $0.5-2 \mathrm{~s}$ with $0.5 \mu \mathrm{m}$ per pixel resolution in the xy dimension, and 4-5 $\mu \mathrm{m}$ steps in the $\mathrm{z}$ dimension. Argon and HeNe-543 lasers were used to excite Fluo-4 AM and Cell Tracker Red CMTPX dyes, respectively. After recording baseline fluorescence for $2 \mathrm{~min}$, $\mathrm{GnRH}$ was applied ( $1 \mathrm{nM}$ in ACSF; Sigma-Aldrich) for $2 \mathrm{~min}$. 
Recordings continued for up to $26 \mathrm{~min}$. ACSF was applied by a pump perfusion system with a constant flux $(1.5 \mathrm{ml} / \mathrm{min})$ that continuously renewed the buffer in the recording chamber. Longlasting effects induced by GnRH were never observed, hence for practical reasons, for plots and statistical analyses only the first 10 min of recordings were considered. Leica Application Suite AF software was used to record and measure fluorescent activity in 7 independent experiments per group.

We obtained relative fluorescence changes $\left(F_{\mathrm{i}} / F_{0}\right)$, where $F_{0}$ is the fluorescence image formed by averaging the first 50 frames of the sequence, and $F_{(i)}$ represents each (i) frame of the recording. We then performed a large-scale analysis investigating rank correlation (Spearman Rank Order test) between $\Delta \mathrm{F}$ values from all $\mathrm{GnRH}$-responding cell pairs to test whether events of gross synchrony between cells occurred during the whole recording, as described previously (Bonnefont et al., 2005). We also studied the correlation coefficients of connected cell pairs along time windows $(p<0.001)$ and in consequence, we decided only to consider 3 meaningful time windows: before (between 100 and $200 \mathrm{~s}$ ), during (between 250 and $350 \mathrm{~s}$ ), and after (500-600 s) GnRH application. We performed complementary statistical tests to assess differences in correlation coefficients within each group (Mann-Whitney rank sum test). Distances between each GnRH-responding cell pair were measured (ImageJ, NIH). We first performed correlation analysis between correlation coefficients from $\mathrm{GnRH}$-responding cells and intercellular distances. If there was a significant correlation, we subsequently compared slopes and intercepts of the regression lines. For this latter analysis, values of $p<0.001$ were considered statistically significant.

Data are presented as mean \pm SEM or as median \pm IQR, as indicated. Statistical analyses were performed using Sigmaplot 11.0 or GraphPad Prism 5. To test for normal distribution of the data, the Kolmogorov-Smirnov test and equal variance by Levene median test were used. Differences between groups were examined using Student's $t$-test, one-way ANOVA with Bonferroni $t$-test for multiple-comparisons, or Mann-Whitney rank sum test as indicated. Values of $p<0.05$ were considered statistically significant for the rest of the analyses.

\section{Gonadectomy}

A small incision directly above the scrotum and, respectively cephally to the iliac crest was made under a mixture of ketamine hydrochloride $(90 \mathrm{mg} / \mathrm{kg}$ ) and xylazine $(5 \mathrm{mg} / \mathrm{kg})$ anesthesia dissolved in phosphate buffered saline (PBS). Testes or ovaries were extracted, ligated with a monofilament suture and removed. Muscle layers and skin were sutured, and mice were singly housed until full recovery from the anesthesia. Blood and tissues were collected 1 week after surgery.

\section{Pituitary Cell Culture}

Eight to sixteen week old wild-type females were used. After decapitation under isoflurane anesthesia, the pituitary gland was dissected out in ice cold Hanks balanced salt solution (HBSS; Life Technologies) plus $10 \mathrm{mM}$ HEPES. Following $45 \mathrm{~min}$ incubation at $37^{\circ} \mathrm{C}$ in $0.25 \%$ trypsin, cells were triturated in the presence of $0.05 \%$ DNAseI. Trypsin was blocked with $10 \%$ FBS. Cells were washed twice with DMEM (Life Technologies) without phenol red and plated in a poly-lysine $(10 \mathrm{ug} / \mathrm{ml}$ in borate buffer, $\mathrm{pH} 8.4)$ coated 24 well plate at $1.5 \times 10^{5}$ cells per well. DMEM containing FBS (5\%; Life Technologies), Pen/Strep (1\%; Life Technologies), non-essential amino acids (1\%; Life Technologies), sodium pyruvate (1\%; Life Technologies), and Glutamax (1\%; Life Technologies) was used as culture medium. After 2 days in vitro (DIV), the cells underwent a $12 \mathrm{~h}$ serum starvation and were then stimulated with 17 ßestradiol $(100 \mathrm{nM}$; Sigma-Aldrich) for 3 or $6 \mathrm{~h}$.

\section{qPCR Analysis}

Tissues were rapidly dissected, frozen on dry ice and stored at $-80^{\circ} \mathrm{C}$. Cells were lysed in RLT buffer and stored at $-80^{\circ} \mathrm{C}$. Total RNA was extracted using the RNeasy Mini Kit (Qiagen, Hilden, Germany). After DNaseI digestion, cDNA was synthesized using random hexamers and SuperScript II reverse transcriptase (Life Technologies, Darmstadt, Germany). Quantitative PCR analysis was performed using the StepOnePlus continuous fluorescence detector (Applied Biosystems Research, Foster City, CA, USA). Product amplification was determined by SYBR Green 1 fluorescence detection. Standard cycling procedures were employed with annealing temperatures of $60^{\circ} \mathrm{C}$. Specific amplicon formation with each primer pair was confirmed by melt curve analysis. Gene expression was quantified relative to $18 \mathrm{~S}$ ribosomal RNA. qPCR measurements were performed in duplicate or triplicate. Primers were: Cx36 sense: 5' TGGCTTCAGTGTTCCA GGCTTGTA 3', Cx36 antisense: 5' CGCTCACAGCAAACATGAACACCA 3', $18 \mathrm{~S}$ sense: $5^{\prime}$ CACACGCTGAGCCAG 3', $18 \mathrm{~S}$ antisense: $5^{\prime}$ AGGTTTGTGATGCCC 3'.

\section{Promoter Analysis}

Position weight matrices for $\mathrm{ER} \alpha$ and $\mathrm{ER} ß$ were retrieved using the MotifDB (Shannon, 2014) package for R (R Core Team, 2015) and matched to the Cx36 promoter retrieved from the UCSC mm10 genome following the workflow "Gene Regulation Transcription Factor Binding Sites" published on bioconductor (http://www.bioconductor.org/).

\section{RESULTS}

To evaluate the input of Cx36 on female reproduction, we performed fecundity tests by mating wild-type (wt) or $\mathrm{C} \times 36^{-/-}$ (Hormuzdi et al., 2001) virgin females with wt proven stud males, and found that $\mathrm{C} \times 36^{-/-}$females produced smaller litters than control females (Figure 1A), while both the percentage of successful matings and the time to produce the first litter were unaltered (data not shown). Furthermore, puberty onset measured as day of vaginal opening was delayed by 3 days in $\mathrm{C} \times 36^{-/-}$females (Figure 1B). Prompted by these findings we continued to characterize the reproductive phenotype in more detail. Analysis of the estrous cycle based on vaginal smear cytology showed that the total duration was unchanged in $\mathrm{C} \times 36^{-/-}$compared to wt females (Figure 1C). However, the relative time spent in estrus was significantly reduced, while the duration of metestrus was prolonged in $\mathrm{C} \times 36^{-/-}$mice 


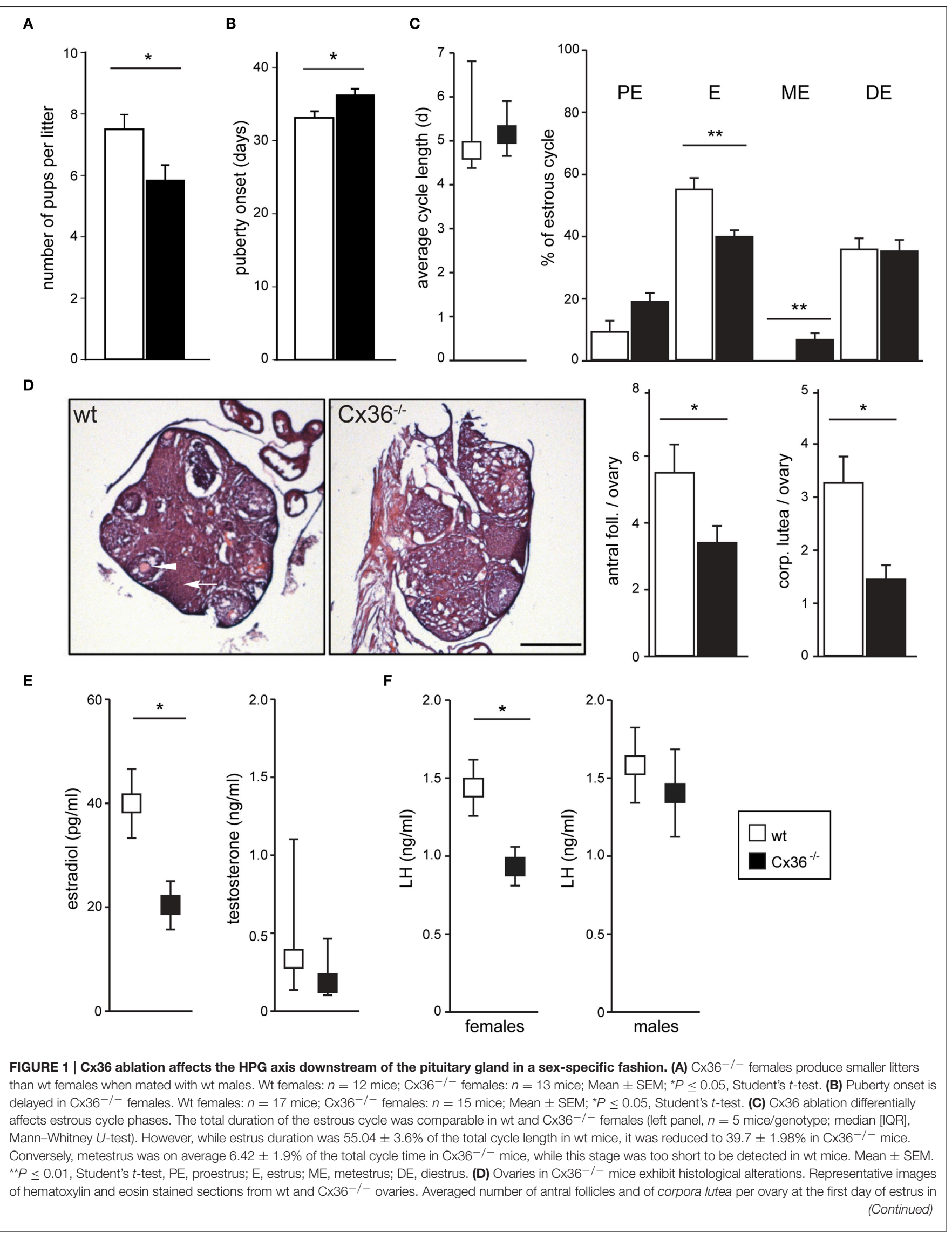




\section{FIGURE 1 | Continued}

wt $\left(n=10\right.$ ovaries/5 mice), Cx36 $/-$ ( $n=12$ ovaries/6 mice). Scale bar: $500 \mu \mathrm{m}$; mean \pm SEM. ${ }^{\star} P \leq 0.05 ;{ }^{* \star} P \leq 0.01$; Student's $t$-test. (E) Following Cx36 ablation, plasma estradiol concentration (measured by HPLC on first day of estrus) is decreased in females whereas testosterone levels in males (measured by RIA) are not affected. Wt females: $n=6$ mice; Cx36-l- females: $n=7$ mice. Mean \pm SEM; ${ }^{*} \leq \leq 0.05$, Student's $t$-test. $n=8$ male mice/genotype. Median [IQR], Mann-Whitney $U$-test. (F) Following Cx36 ablation, plasma LH concentration (determined by RIA) is altered in females (measured on the first day of estrus), but not in males. Wt females: $n=14$ mice; Cx36 ${ }^{-/}$females: $n=11$ mice; $n=8$ male mice/genotype. Mean $\pm \mathrm{SEM}$; $P \leq 0.05$, Student's $t$-test.

(Figure 1C). Histological analysis of ovaries harvested on the first day of estrus showed a drastic reduction in the number of antral follicles and corpora lutea in $\mathrm{C} \times 36^{-/-}$mice compared to control (Figure 1D), which is suggestive of reduced ovulation. Accordingly, plasma concentrations of estradiol were decreased by $47 \%$ in $\mathrm{C} \times 36^{-/-}$females, and $\mathrm{LH}$ concentrations were reduced by $40 \%$, when both were measured in the morning on the first day of estrus (Figures 1E,F). Of note, plasma testosterone levels as well as plasma LH in males were unchanged (Figures 1E,F), suggesting a specific role of $\mathrm{Cx} 36$ in the female hypothalamic-pituitary-gonadal (HPG) axis.

Intrigued by these observations we set out to investigate the role of Cx36 within the HPG axis, and first established the site and pattern of expression. We quantified Cx36 mRNA expression levels in pituitaries and gonads from male and female wt mice using qPCR. The expression level in the pituitary gland was comparable in the two sexes, and there was only very low or no expression in testes and ovaries, respectively (Supplementary Figure 1A). Given the heterogeneity of the hypothalamus with respect to function, we investigated Cx36 expression directly in $\mathrm{GnRH}$ neurons. To this end we employed transgenic mice that we had previously characterized (Christie et al., 2005) and that showed faithful expression of the fusion protein Cx36-EGFP under the control of the Cx36 promoter. In agreement with a previous study, (Campbell et al., 2011) we found no evidence for Cx36-EGFP expression and therefore Cx36 mediated gap junction coupling between GnRH neurons (Supplementary Figure 1B). Thus, within the HPG axis, we detected Cx36 expression only in the pituitary gland.

To determine the cellular identity of Cx36 expressing cells in the anterior pituitary (AP), we took again recourse to Cx36-EGFP transgenic female mice. Double labeling for EGFP and $\mathrm{LH}$ (as well as EGFP and FSH) revealed that $99.63 \pm$ $0.37 \%$ of $\mathrm{LH}^{+}$cells (as well as $87.27 \pm 2.63 \%$ of $\mathrm{FSH}^{+}$cells) expressed EGFP. Conversely, the percentage of $\mathrm{EGFP}^{+}$cells expressing either $\mathrm{LH}$ or FSH was $99.62 \pm 0.37 \%$, and 95.00 $\pm 2.26 \%$, respectively (mean $\pm \mathrm{SEM}, n=3$ mice), showing that Cx36 was almost exclusively expressed by gonadotropes of the AP (Figure 2A and Supplementary Figure 1C). In control experiments we established that $\mathrm{C} \times 36$ ablation did not affect the average number of gonadotropes (Supplementary Figure 2). Higher magnification images revealed that Cx36-EGFP localized frequently to membrane appositions of $\mathrm{LH}^{+}$cells (Figure 2A, arrowheads), suggesting that gonadotropes might be connected via Cx36-containing gap junctions. We further confirmed the specific expression of Cx36 in gonadotrope cells in the pituitary of wild-type female mice employing in situ hybridization to detect Cx36 mRNA, and immunohistochemistry against LH (Supplementary Figures 1D,E).
To provide functional evidence for gap junction mediated coupling between gonadotropes, we performed paired patchclamp recordings from Cx36-EGFP expressing gonadotropes in acute slices of young female mice (Figure 2B). As previously shown, we can exclude that the Cx36-EGFP fusion protein forms channels on its own as it needs to partner with wt Cx36 (Helbig et al., 2010). In 6 out of 9 tested Cx36-EGFP positive cell pairs, hyperpolarizing current injection in one cell elicited a detectable voltage deflection in the other cell (Figure 2C). On average, electrical coupling was symmetrical, i.e., was not dependent on which cell of the pair underwent current injection, thus demonstrating the presence of gap junctions between gonadotropes. The strength of coupling was $0.025 \pm 0.008$ $(n=6)$.

To substantiate the functional role of $\mathrm{Cx} 36$ on the activity of gonadotropes, we assessed $\mathrm{GnRH}$-induced $\mathrm{Ca}^{2+}$ responses in acute pituitary slices from wt and $\mathrm{C} \times 36^{-/-}$mice that were in estrus. We detected GnRH-induced increases in intracellular $\mathrm{Ca}^{2+}$ both in wt and $\mathrm{Cx} 36^{-/-}$pituitary cells (Figure 3A). In both genotypes, typically two types of responses were observed, namely biphasic or oscillatory responses (Supplementary Figures 3A-D). The degree of synchrony was determined by performing a pairwise comparison of the relative fluorescence values for all $\mathrm{GnRH}$ responsive cells and averages of one experiment were plotted as heat maps (Figures 3B,C). Notably, there was an increase in the correlation coefficients in the wt upon GnRH stimulation. There was no difference before and after $\mathrm{GnRH}$ stimulation between genotypes (Figures 3D,F), whilst GnRH stimulation led to an increase in the number of cell pairs with enhanced synchrony in wt compared to $\mathrm{Cx} 36^{-/-}$(Figure 3E). We further evaluated the influence of $\mathrm{Cx} 36$ deletion on the network activity by taking into consideration the intercellular distance for each cell pair (Figure 3G). Indeed, at a larger scale, Cx36 ablation affected the synchrony of network activity only during the application of $\mathrm{GnRH}$ (Figure $3 \mathbf{H}$ and Supplementary Figure 4). Thus, there was a steeper negative slope of the regression line for correlation coefficients between cell pairs obtained from $\mathrm{Cx} 36^{-/-}$pituitary slices. This reflects decreased coupling with increasing intercellular distance, thus highlighting the role of gap junction coupling in the entrainment of gonadotropes to a common activity pattern. Surprisingly, average correlation coefficients between cells in close proximity (up to 5 $\mu \mathrm{m}$ distance between cell membranes) were reduced in $\mathrm{Cx} 36^{-/-}$ slices throughout the experiment, unmasking a role for gap junction coupling under both basal and stimulated conditions (Figure 3I).

Given the estrous cycle dependent pattern of $\mathrm{LH}$ secretion, we wondered whether Cx36 expression itself is regulated across the estrous cycle. Hence, we analyzed Cx36 mRNA in estrus 

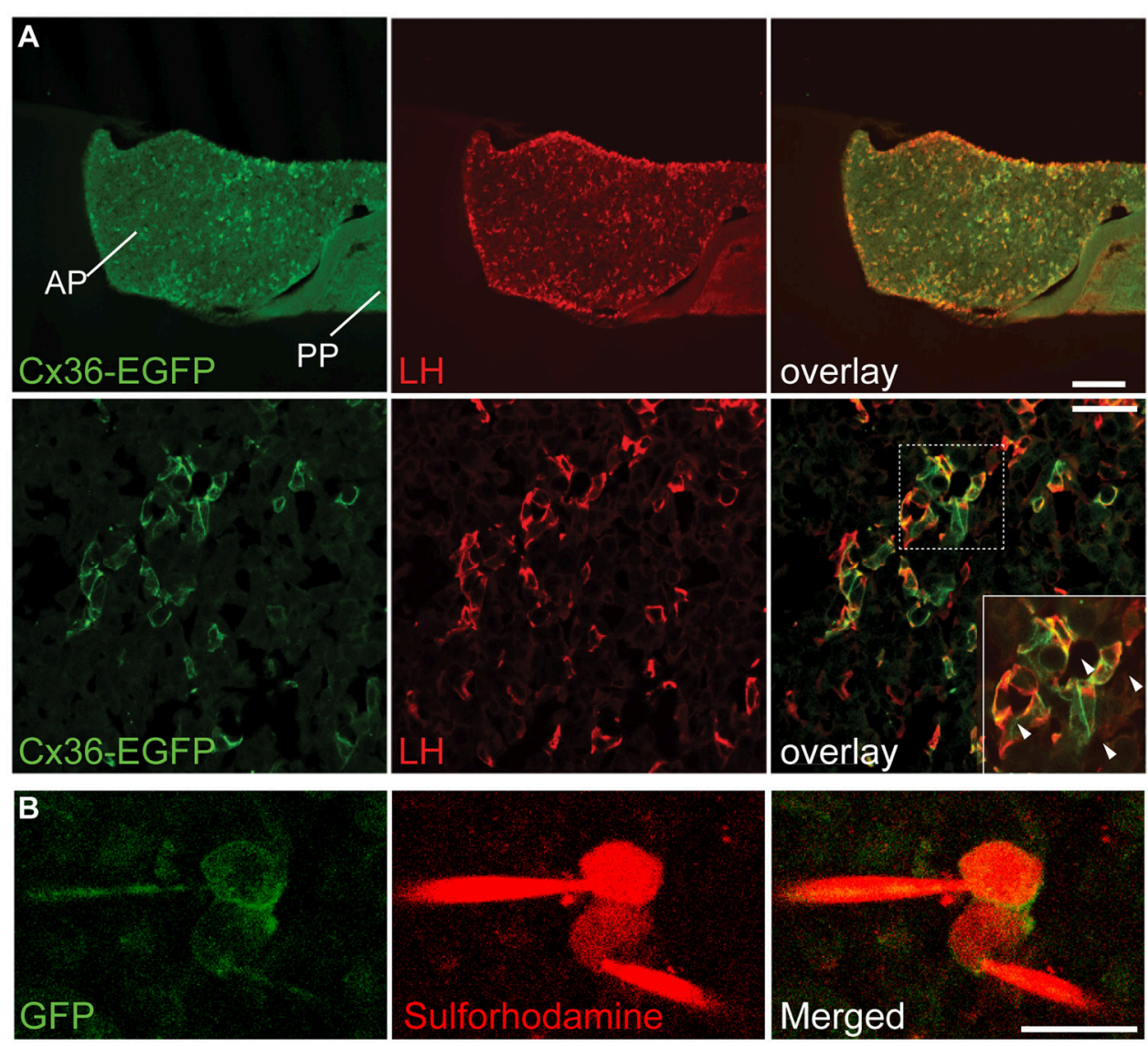

C
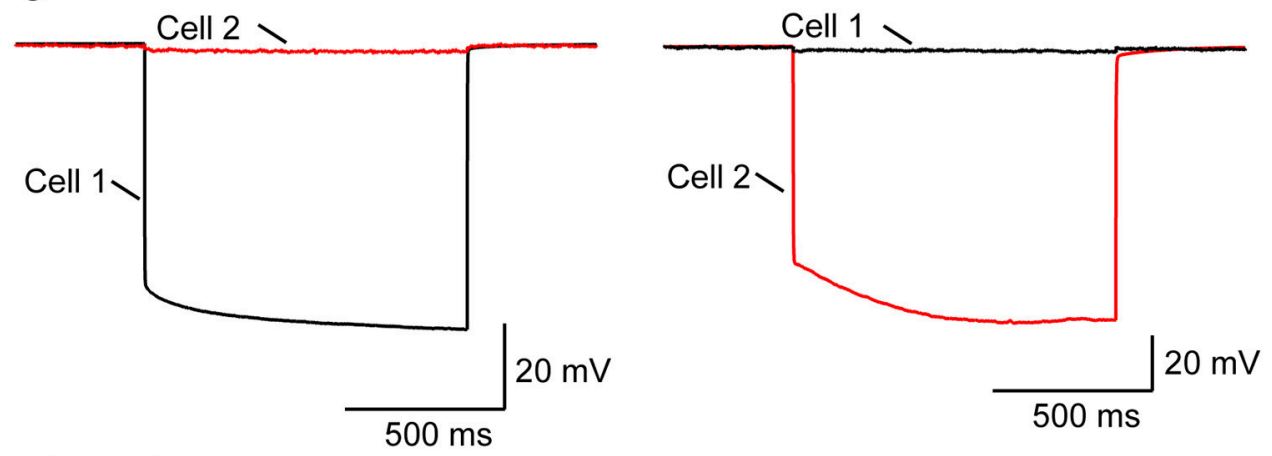

Stim. cell 1

Stim. cell 2

$\longdiv { 8 0 0 \mathrm { pA } }$

Cell 2 - expanded

Cell 1 - expanded
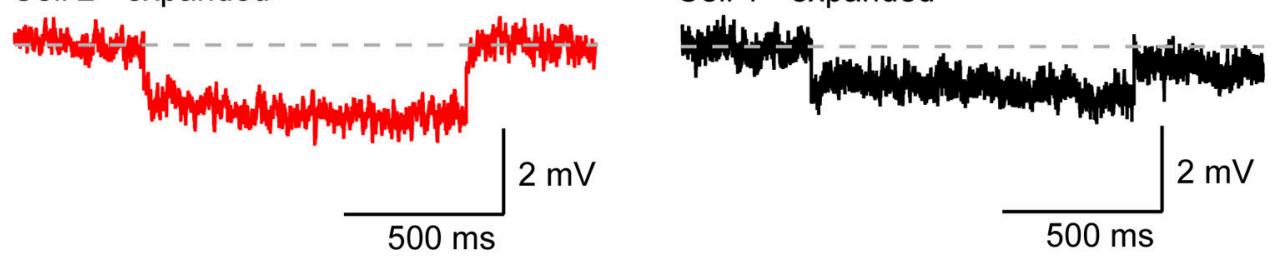

FIGURE 2 | Gonadotropes of the pituitary gland are coupled via Cx36-containing gap junctions. (A) Cx36-EGFP is expressed in $\mathrm{LH}^{+}$cells in the AP. Lower panels show higher magnification. Arrowheads in the inset highlight the localization of Cx36-EGFP signal to membrane appositions of $\mathrm{LH}^{+}$cells. $\mathrm{AP}$, anterior pituitary; PP, posterior pituitary. (B) Confocal microscopy images of two adjacent EGFP+ ${ }^{+}$cells in the AP immediately before (left panels) and after (right panels) whole-cell 
FIGURE 2 | Continued

patch-clamp. Sulforhodamine (in red) was added to the intracellular solution to help visualize patch-clamped cells. (C) The voltage response of cell 1 (top left) after hyperpolarizing current injection (middle) is detectable in cell 2, albeit with a much reduced amplitude. Conversely, the voltage response of cell 2 (top right) can be detected in cell 1 . Six out of nine tested pairs showed such a response.

A

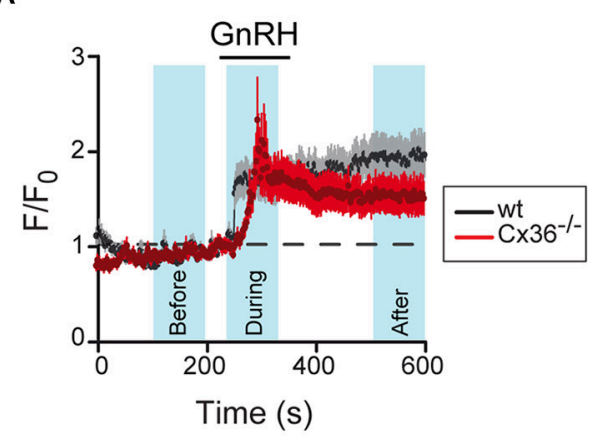

B

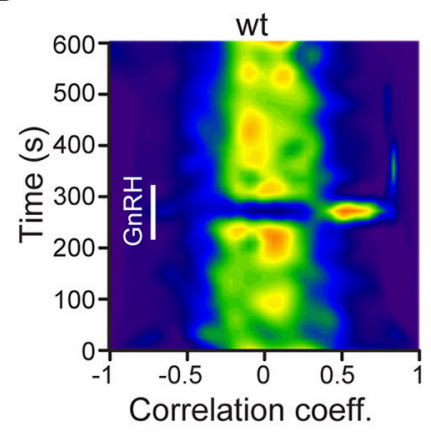

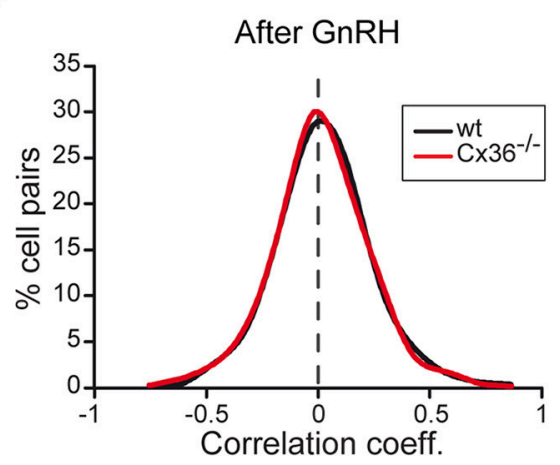

I

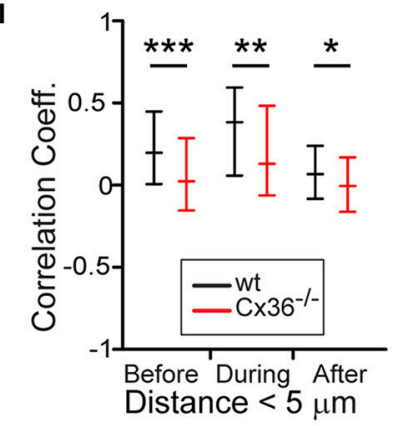

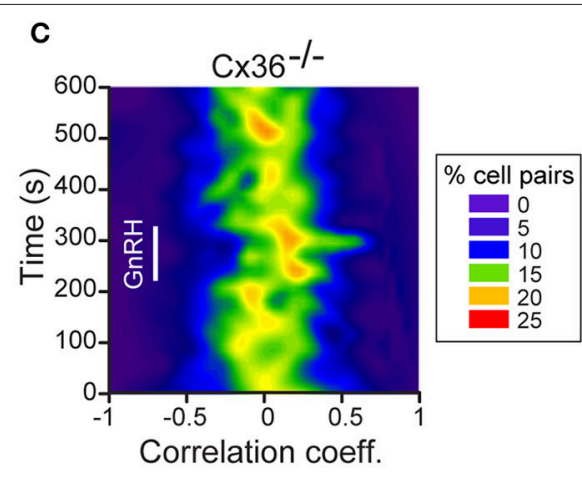

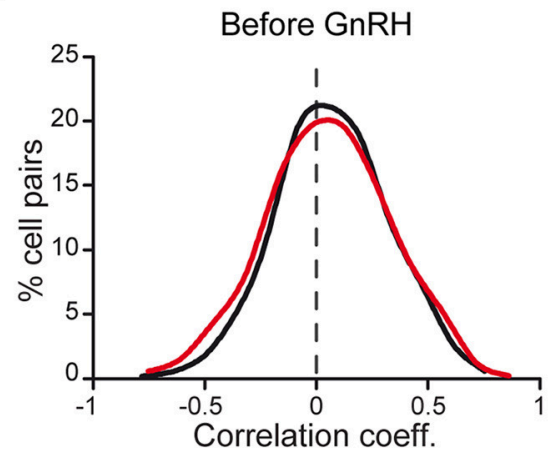

G

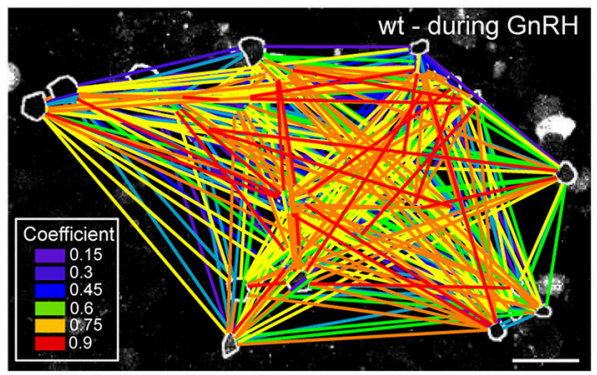

E

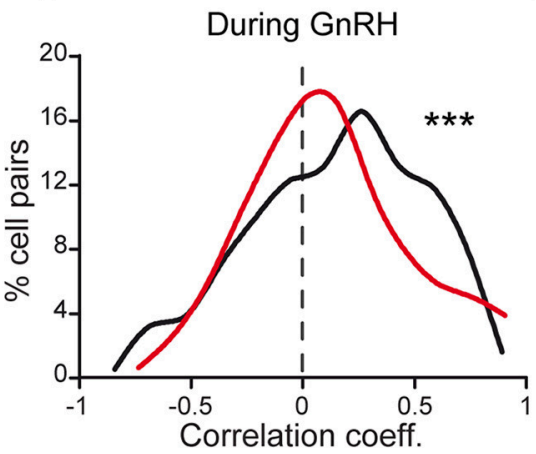

H

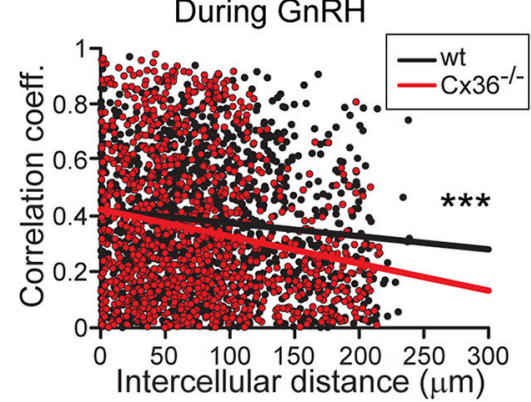

FIGURE 3 | Deficient electrical coupling between gonadotropes in $\mathbf{C x 3 6 - / - ~ m i c e ~ a s ~ r e v e a l e d ~ b y ~} \mathbf{C a}^{\mathbf{2}+}$ imaging. (A) GnRH-induced calcium response in wt and $\mathrm{C} \times 36^{-/-}$AP. Representative examples of averaged recordings from one experiment. GnRH ( $\left.1 \mathrm{nM}\right)$ was applied for 2 min. Number of cells: wt $n=32 ; \mathrm{C} \times 36^{-/-}$ $n=14$. Data represent mean \pm SEM. Blue areas represent time windows selected for statistical analysis. (B, C) GnRH evokes stronger and more coordinated responses in wt (B) than in Cx36-/- (C) pituitaries. Representative heat maps from one wt and one Cx36 $6^{-/-}$AP (528 and 351 cell pairs, respectively) showing temporal dynamic changes of correlated activity (Spearman coefficient). (D-F) Cx36 ablation effects GnRH-induced, but not basal synchrony. Distribution of Spearman correlation coefficients for cell pairs before (D), during (E), and after (F) GnRH application. Although some cell pairs displayed high coefficient correlation values, no large-scale synchrony was observed before GnRH application. Seven experiments/genotype; wt $n=1908$; Cx36 ${ }^{-/} n=1951$ cell pairs, Mann-Whitney Rank Sum Test. ${ }^{* \star} P \leq 0.001$. (G) Illustrative example of one correlation map identifying GnRH-responsive cell pairs in wt mice during GnRH application. All $\mathrm{GnRH}$-responsive cell pairs are connected with lines. Colors represent the correlation intensity according to Spearman correlation coefficients. Scale bar: $25 \mu \mathrm{m}$. (H) Comparative linear regression analysis between the positive values of Spearman correlation coefficients and intercellular distances showing that only during $\mathrm{GnRH}$ application the slopes are significantly different when comparing wt and Cx36-/- . For more details, see Supplementary Figure S3. Seven experiments/genotype; wt $n$ $=1908$; Cx36 ${ }^{-/-} n=1951$ cell pairs. ${ }^{* \star} P \leq 0.001$. (I) Synchrony between $\mathrm{C} \times 36^{-/-}$cells is decreased also before and after GnRH application when considering only short-distance coupling $(<5 \mu \mathrm{m})$. Spearman correlation coefficients obtained from 7 experiments/genotype, wt $n=82$; Cx36 ${ }^{-/-} n=93$ cell pairs, median [IQR], Mann-Whitney Rank Sum Test. ${ }^{\star} P \leq 0.05,{ }^{* *} P \leq 0.01$; ${ }^{* \star \star} P \leq 0.001$. 
and diestrus, and found a two-fold increase of Cx36 mRNA in estrus (Figure 4A). Subsequently, we examined Cx36 expression following ovariectomy and orchiectomy to investigate whether sex steroids played a role in the regulation of Cx36 expression. Of note, ovariectomy in females caused an about two-fold increase of Cx36 expression, while castration of males had no impact on Cx36 expression levels (Figure 4B). Using a bioinformatics approach, we searched $5 \mathrm{~kb}$ of the $\mathrm{Cx} 36$ promoter sequence upstream of the transcription start site (TSS) for putative estrogen response elements to determine if the repression of Cx36 expression could be a direct effect of ER binding to the promoter region of $\mathrm{Cx} 36$. In support of this hypothesis,
A

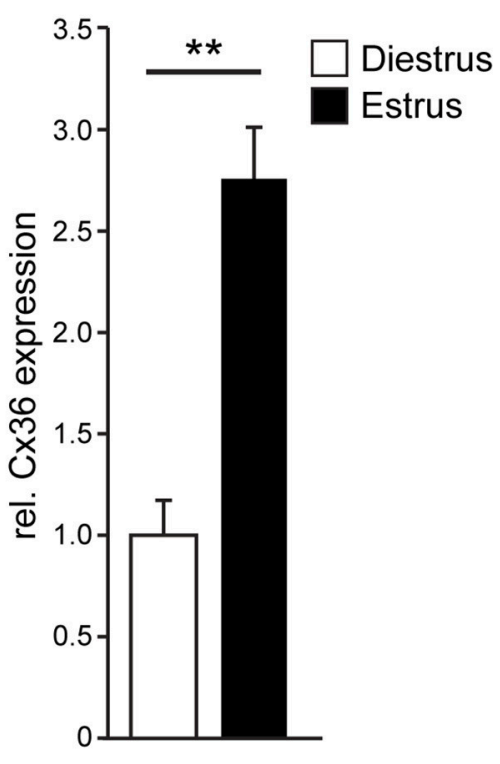

B

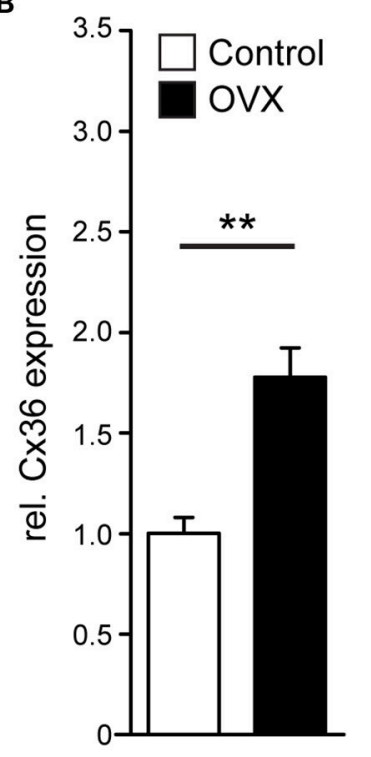

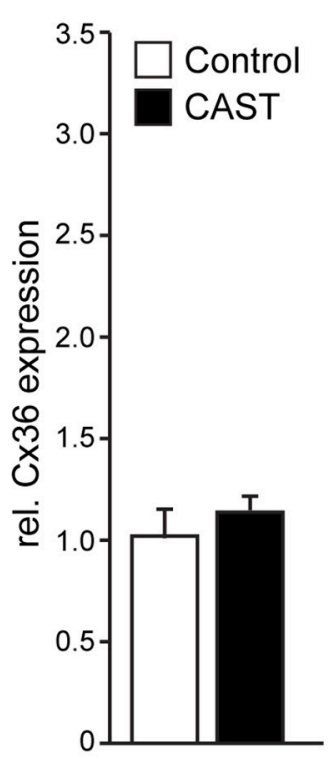

C
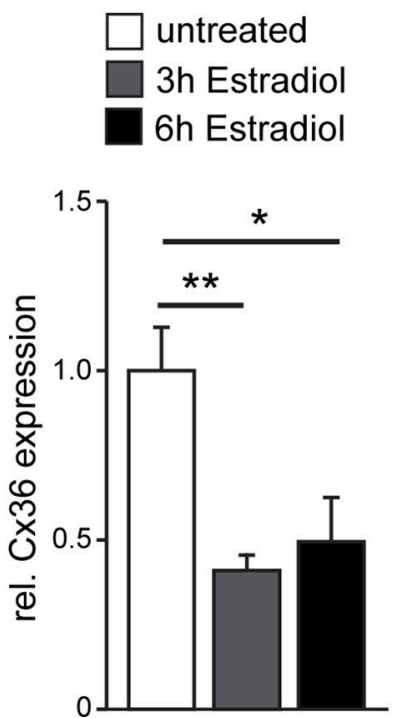

D

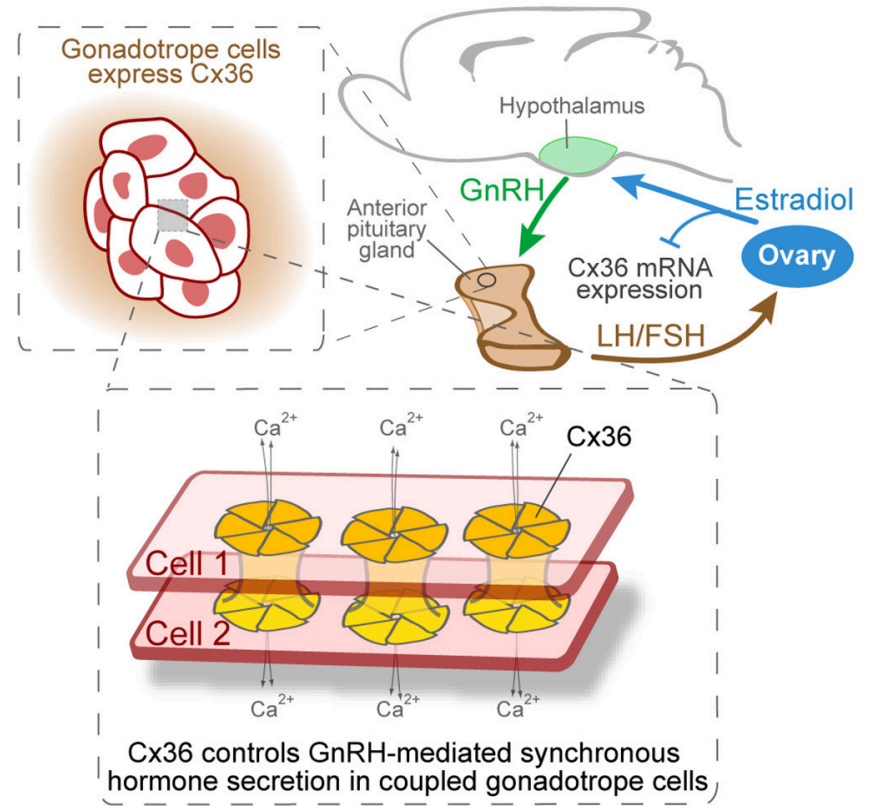

FIGURE 4 | Cx36 expression is regulated in a sex-specific manner. (A) Cx36 mRNA expression in the pituitary gland of female wt mice is augmented in estrus $(n=9)$ compared to diestrus $(n=5)$ as shown by qPCR analysis. Mean \pm SEM; ${ }^{* *} P \leq 0.01$; Student's $t$-test. (B) Ovariectomy results in increased Cx36 mRNA expression $\left(n=6\right.$, control $n=9$ ) while castration $(n=4$, control $n=3)$ has no effect on Cx36 mRNA expression in the pituitary gland of males. Mean \pm SEM; ${ }^{\star *} P \leq$ 0.01; Student's $t$-test. (C) Treatment of cultured pituitary cells from wt females with estradiol leads to a rapid suppression of mRNA expression. $n=4$ independent experiments, performed in triplicate or quadruplicate. Mean $\pm \mathrm{SEM}$; ${ }^{\star *} P \leq 0.01 ;{ }^{*} P \leq 0.05$; ANOVA, Bonferroni post-hoc test. (D) Schematic diagram illustrating CX36 action on the hypothalamic-pituitary-ovarian axis. Cx36 controls GnRH-mediated synchronous hormone secretion (LH/FSH) in coupled gonadotrope cells in the pituitary gland. LH and/or FSH stimulate estradiol production in the ovaries, which in turn represses Cx36 mRNA expression in the pituitary gland. 
we found two putative binding sites for ERalpha with $75 \%$ minimal matching scores located 725 and 3109 bp upstream of the TSS (Supplementary Figure 5A), and one putative binding site for ERbeta 2458 bp upstream of the TSS with an $88 \%$ minimal matching score (Supplementary Figure 5B). To address if estradiol can directly influence the expression level of Cx36 in gonadotropes, we exposed cultured wt pituitary cells to estradiol for 3 or $6 \mathrm{~h}$. Indeed, this treatment induced a significant decrease of Cx36 mRNA expression compared to controls, further corroborating the finding that steroid hormones, specifically estradiol, regulate Cx36 expression (Figure 4C).

Thus, suppression of Cx36 mRNA by ovarian steroids is indicative of a gender-specific gap junction function within the HPG axis, specifically in the control of GnRH-mediated synchronous gonadotrope secretion.

\section{DISCUSSION}

In summary our results demonstrate that Cx36 mediated cell-cell communication within the AP is essential to translate pulsatile $\mathrm{GnRH}$ stimulation into appropriate simultaneous activation of gonadotropes in females, and that this cell-cell communication is negatively regulated by estradiol (Figure 4D). In the absence of Cx36, LH levels were decreased, estrous cycle phases were shifted, ovulation was impaired, and litter size was reduced. We postulate that the effects within the HPG axis in female mice are downstream of $\mathrm{GnRH}$ neurons since they were not observed in mutant mice in which $\mathrm{Cx} 36$ was conditionally ablated in forebrain neurons (Campbell et al., 2011).

Gap junctions have been reported to couple other types of pituitary cells where they help to maintain basal activity and mediate synchronous population responses upon stimulation (Guérineau et al., 1998; Fauquier et al., 2001; Hodson et al., 2012). Here we directly demonstrate the presence of gap junctions between gonadotropes in the AP by simultaneous electrophysiological recordings from pairs of neighboring gonadotropes. After establishing the exclusive expression of Cx36-EGFP in gonadotropes, we took advantage of this finding to identify gonadotropes in live pituitary slices. Paired patchclamp recordings of neighboring EGFP-positive cells revealed symmetrical electrical coupling, thus demonstrating the presence of gap junctions (Hormuzdi et al., 2001). The coupling coefficient was in the lower range of what was reported previously for neurons coupled via Cx36-containing gap junctions (Gibson et al., 1999; Meyer et al., 2002). Gap junctions between gonadotropes appear to be a common feature of this cell type as they were detected between $67 \%$ of tested cell pairs. This is similar to the extent of gap junction coupling identified by dyetransfer between lactotropes and somatotropes (Guérineau et al., 1998; Hodson et al., 2012).

Using $\mathrm{Ca}^{2+}$ imaging experiments in acute pituitary slices from wt and $\mathrm{Cx} 36^{-/-}$females we established the functional relevance of this coupling at the level of the gonadotrope network. Ablation of $\mathrm{Cx} 36$ resulted in asynchronous $\mathrm{Ca}^{2+}$ activity in gonadotropes upon GnRH stimulation. Taking into account only cells in close proximity, i.e., neighboring cells, we found a significant decorrelation of $\mathrm{Ca}^{2+}$ activity also under basal conditions in Cx36 deficient pituitary slices. Similarly, $\mathrm{Ca}^{2+}$ transients in spontaneously coactive somatotropes were reported to desynchronize under basal conditions upon incubation with the general gap junction blocker halothane (Guérineau et al., 1998). Our findings show that $\mathrm{Cx} 36$ is crucial to maintain synchrony of $\mathrm{Ca}^{2+}$ transients between neighboring gonadotropes under both basal conditions and upon GnRH stimulation, and hence suggest that $\mathrm{Cx} 36$-containing gap junctions are necessary to ensure efficient, synchronous secretion of gonadotropins from the AP. It is well-documented that LH secretion varies greatly during the course of the estrous cycle, both with respect to pulse frequency and amplitude (Baird, 1978). If gap junction coupling is crucial for the generation of peak secretion as we and others argue (Guérineau et al., 1998), then Cx36 expression should change during the course of the estrous as well. Indeed, as shown in this study, Cx36 mRNA expression in the AP was increased in estrus compared to diestrus, and after ovariectomy compared to control, i.e., during two states in which LH pulse frequency is maximal and would thus require well-synchronized secretory activity (Baird, 1978; Leipheimer and Gallo, 1983). Notably, Hodson et al. showed that synchronization between lactotropes increases demand dependently in lactating females, and that the increased synchrony is also due to augmented gap junction coupling (Hodson et al., 2012). Our results suggest that in gonadotropes the regulation of gap junction coupling is at least in part supported by an increased expression of Cx36.

The increase of Cx36 expression following ovariectomy implies gonadal steroids as possible mediators (Weick and Noh, 1984). Testing this directly, we found indeed that estradiol reduced Cx36 expression in cultured pituitary cells. Furthermore, we detected putative estradiol response elements within the Cx36 promoter, which together with the fast time course of the decrease in mRNA levels, lends credence to a scenario in which estradiol is a direct regulator of Cx36 expression. The estradiol induced reduction of Cx36 mRNA expression in cell culture cannot be directly compared with the in vivo scenario where other estradiol kinetics may be expected. Hence, further research is warranted to understand how estradiol levels in each estrus phase translate into gap junction coupling of differential strength. Also, ovariectomy and cell culture are artificial situations that deprive gonadotropes of more than one factor. However, they prove useful in obtaining mechanistic insight as was the case in this study where we could show that estradiol is one factor (several others are likely to also contribute) that regulates the expression of $\mathrm{Cx} 36$ and hence the extent of gap junction communication between gonadotropes. These results suggest an additional negative estradiol-mediated feedback loop that targets the fine-tuning of $\mathrm{LH}$ release in the pituitary gland by reducing the synchronization of gonadotropes following phases of physiologically high estradiol.

Thus, a local mechanism of electrotonically coupled gonadotropes at the pituitary level must be added to the complex system controlling female reproduction, and alterations of the intra-pituitary crosstalk may contribute to the pathogenesis of frequently occurring disruptions of menstrual cycle, anovulation and infertility in women (Fritz and Speroff, 2010; Unuane et al., 2011; ESHRE Capri Workshop Group, 2012). 


\section{AUTHOR CONTRIBUTIONS}

CG, HM, and VG conceived the study. CG, DG, CL, LR, and DB performed experiments. CG, DG, CL, and DB analyzed data. CG, DG, CL, VG, and HM wrote the paper.

\section{FUNDING}

GR 3619/2-1 and GR 3619/3-1 grants from the German Research Foundation (DFG), and grant within the Collaborative Research Center (SFB) 1134 to VG.

\section{ACKNOWLEDGMENTS}

The authors thank Dr. K.-Y. Francis Pau (Endocrine Technology \& Support Lab, Oregon National Primate Research Center,

\section{REFERENCES}

Al-Ubaidi, M. R., White, T. W., Ripps, H., Poras, I., Avner, P., Gomès, D., et al. (2000). Functional properties, developmental regulation, and chromosomal localization of murine connexin36, a gap-junctional protein expressed preferentially in retina and brain. J. Neurosci. Res. 59, 813-826. doi: 10.1002/(SICI) 1097-4547(20000315)59:6<813::AID-JNR14>3.0.CO;2-\#

Baird, D. T. (1978). Pulsatile secretion of LH and ovarian estradiol during the follicular phase of the sheep estrous cycle. Biol. Reprod. 18, 359-364. doi: 10.1095/biolreprod18.3.359

Belchetz, P. E., Plant, T. M., Nakai, Y., Keogh, E. J., and Knobil, E. (1978). Hypophysial responses to continuous and intermittent delivery of hypopthalamic gonadotropin-releasing hormone. Science 202, 631-633. doi: $10.1126 /$ science. 100883

Belluardo, N., Mudò, G., Trovato-Salinaro, A., Le Gurun, S., Charollais, A., SerreBeinier, V., et al. (2000). Expression of connexin36 in the adult and developing rat brain. Brain Res. 865, 121-138. doi: 10.1016/S0006-8993(00)02300-3

Bennett, M. V., and Zukin, R. S. (2004). Electrical coupling and neuronal synchronization in the Mammalian brain. Neuron 41, 495-511. doi: 10.1016/S0896-6273(04)00043-1

Bonnefont, X., Lacampagne, A., Sanchez-Hormigo, A., Fino, E., Creff, A., Mathieu, M. N., et al. (2005). Revealing the large-scale network organization of growth hormone-secreting cells. Proc. Natl. Acad. Sci. U.S.A. 102, 16880-16885. doi: 10.1073/pnas.0508202102

Burks, D. J., Font de Mora, J., Schubert, M., Withers, D. J., Myers, M. G., Towery, H. H., et al. (2000). IRS-2 pathways integrate female reproduction and energy homeostasis. Nature 407, 377-382. doi: 10.1038/35030105

Campbell, R. E., Ducret, E., Porteous, R., Liu, X., Herde, M. K., Wellerhaus, K., et al. (2011). Gap junctions between neuronal inputs but not gonadotropinreleasing hormone neurons control estrous cycles in the mouse. Endocrinology 152, 2290-2301. doi: 10.1210/en.2010-1311

Campbell, R. E., Gaidamaka, G., Han, S. K., and Herbison, A. E. (2009). Dendrodendritic bundling and shared synapses between gonadotropin-releasing hormone neurons. Proc. Natl. Acad. Sci. U.S.A. 106, 10835-10840. doi: 10.1073/pnas.0903463106

Christie, J. M., Bark, C., Hormuzdi, S. G., Helbig, I., Monyer, H., and Westbrook, G. L. (2005). Connexin 36 mediates spike synchrony in olfactory bulb glomeruli. Neuron 46, 761-772. doi: 10.1016/j.neuron.2005.04.030

Deans, M. R., Gibson, J. R., Sellitto, C., Connors, B. W., and Paul, D. L. (2001). Synchronous activity of inhibitory networks in neocortex requires electrical synapses containing connexin36. Neuron 31, 477-485. doi: 10.1016/S08966273(01)00373-7

Desarmenien, M. G., Jourdan, C., Toutain, B., Vessieres, E., Hormuzdi, S. G., and Guerineau, N. C. (2013). Gap junction signalling is a stress-regulated component of adrenal neuroendocrine stimulus-secretion coupling in vivo. Nat. Commun. 4:2938. doi: 10.1038/ncomms3938
Oregon, USA) for RIA measurements of plasma LH levels, Miriam Kernert and Marina Eliava for the help with immunohistochemistry, R. Benoit (McGill University, Montreal, Canada) for providing LR1 antibodies, C.F. Ibáñez (Karolinska Institute, Stockholm, Sweden) for providing the infrastracture for the final experiments carried out by CG, Tim Holland-Letz for the help with statistical analysis, and Matthias Schick from the Genomics and Proteomics Core Facility of DKFZ for technical assistance.

\section{SUPPLEMENTARY MATERIAL}

The Supplementary Material for this article can be found online at: http://journal.frontiersin.org/article/10.3389/fnmol. 2016.00065

ESHRE Capri Workshop Group (2012). Health and fertility in World Health Organization group 2 anovulatory women. Hum. Reprod. Update 18, 586-599. doi: 10.1093/humupd/dms019

Fauquier, T., Guerineau, N. C., McKinney, R. A., Bauer, K., and Mollard, P. (2001). Folliculostellate cell network: a route for long-distance communication in the anterior pituitary. Proc. Natl. Acad. Sci. U.S.A. 98, 8891-8896. doi: $10.1073 /$ pnas. 151339598

Fritz, M. A., and Speroff, L. (eds.) (2010). "Female infertility," in Clinical Gynecologic Endocrinology and Infertility, 8th Edn. (Philadelphia: Lippincott Williams \& Wilkins), 1137-1190.

Gambacciani, M., Liu, J. H., Swartz, W. H., Tueros, V. S., Yen, S. S., and Rasmussen, D. D. (1987). Intrinsic pulsatility of luteinizing hormone release from the human pituitary in vitro. Neuroendocrinology 45, 402-406. doi: $10.1159 / 000124765$

Gibson, J. R., Beierlein, M., and Connors, B. W. (1999). Two networks of electrically coupled inhibitory neurons in neocortex. Nature 402, 75-79. doi: $10.1038 / 47035$

Guérineau, N. C., Bonnefont, X., Stoeckel, L., and Mollard, P. (1998). Synchronized spontaneous $\mathrm{Ca}^{2+}$ transients in acute anterior pituitary slices. J. Biol. Chem. 273, 10389-10395. doi: 10.1074/jbc.273.17.10389

Han, S. Y., McLennan, T., Czieselsky, K., and Herbison, A. E. (2015). Selective optogenetic activation of arcuate kisspeptin neurons generates pulsatile luteinizing hormone secretion. Proc. Natl. Acad. Sci. U.S.A. 112, 13109-13114. doi: $10.1073 /$ pnas. 1512243112

Helbig, I., Sammler, E., Eliava, M., Bolshakov, A. P., Rozov, A., Bruzzone, R., et al. (2010). In vivo evidence for the involvement of the carboxy terminal domain in assembling connexin 36 at the electrical synapse. Mol. Cell. Neurosci. 45, 47-58. doi: 10.1016/j.mcn.2010.05.008

Hodson, D. J., Schaeffer, M., Romanò, N., Fontanaud, P., Lafont, C., Birkenstock, J., et al. (2012). Existence of long-lasting experience-dependent plasticity in endocrine cell networks. Nat. Commun. 3, 605. doi: 10.1038/ncomms1612

Hormuzdi, S. G., Pais, I., LeBeau, F. E., Towers, S. K., Rozov, A., Buhl, E. H., et al. (2001). Impaired electrical signaling disrupts gamma frequency oscillations in connexin 36-deficient mice. Neuron 31, 487-495. doi: 10.1016/S08966273(01)00387-7

Leipheimer, R. E., Bona-Gallo, A., and Gallo, R. V. (1984). The influence of progesterone and estradiol on the acute changes in pulsatile luteinizing hormone release induced by ovariectomy on diestrus day 1 in the rat. Endocrinology 114, 1605-1612. doi: 10.1210/endo-114-5-1605

Leipheimer, R. E., and Gallo, R. V. (1983). Acute and long-term changes in central and pituitary mechanisms regulating pulsatile luteinizing hormone secretion after ovariectomy in the rat. Neuroendocrinology 37, 421-426. doi: $10.1159 / 000123587$

Long, M. A., Deans, M. R., Paul, D. L., and Connors, B. W. (2002). Rhythmicity without synchrony in the electrically uncoupled inferior olive. J. Neurosci. 22, 10898-10905. 
Martin, A. O., Mathieu, M. N., Chevillard, C., and Guérineau, N. C. (2001). Gap junctions mediate electrical signaling and ensuing cytosolic $\mathrm{Ca}^{2+}$ increases between chromaffin cells in adrenal slices: a role in catecholamine release. J. Neurosci. 21, 5397-5405.

Meyer, A. H., Katona, I., Blatow, M., Rozov, A., and Monyer, H. (2002). In vivo labeling of parvalbumin-positive interneurons and analysis of electrical coupling in identified neurons. J. Neurosci. 22, 7055-7064.

Papanicolaou, G. N. (1942). A new procedure for staining vaginal smears. Science 95, 438-439. doi: 10.1126/science.95.2469.438

Pau, K. Y., Orstead, K. M., Hess, D. L., and Spies, H. G. (1986). Feedback effects of ovarian steroids on the hypothalamic-hypophyseal axis in the rabbit. Biol. Reprod. 35, 1009-1023. doi: 10.1095/biolreprod35.4.1009

Rasmussen, L. E., Buss, I. O., Hess, D. L., and Schmidt, M. J. (1984). Testosterone and dihydrotestosterone concentrations in elephant serum and temporal gland secretions. Biol. Reprod. 30, 352-362. doi: 10.1095/biolreprod30.2.352

Ravier, M. A., Güldenagel, M., Charollais, A., Gjinovci, A., Caille, D., Söhl, G., et al. (2005). Loss of connexin36 channels alters beta-cell coupling, islet synchronization of glucose-induced $\mathrm{Ca}^{2+}$ and insulin oscillations, and basal insulin release. Diabetes 54, 1798-1807. doi: 10.2337/diabetes.54.6.1798

R Core Team (2015). R: A Language and Environment for Statistical Computing. (Vienna).

Serre-Beinier, V., Le Gurun, S., Belluardo, N., Trovato-Salinaro, A., Charollais, A., Haefliger, J. A., et al. (2000). Cx36 preferentially connects beta-cells within pancreatic islets. Diabetes 49,727-734. doi: 10.2337/diabetes.49.5.727

Shannon, P. (2014). MotifDB: An Annotated Collection of Protein-DNA Binding Sequence Motifs. R package version 1.14.0.

Söhl, G., Maxeiner, S., and Willecke, K. (2005). Expression and functions of neuronal gap junctions. Nat. Rev. Neurosci. 6, 191-200. doi: 10.1038/nrn1627

Tse, A., Tse, F. W., Almers, W., and Hille, B. (1993). Rhythmic exocytosis stimulated by GnRH-induced calcium oscillations in rat gonadotropes. Science 260, 82-84. doi: 10.1126/science.8385366

Uenoyama, Y., Nakamura, S., Hayakawa, Y., Ikegami, K., Watanabe, Y., Deura, C., et al. (2015). Lack of pulse and surge modes and glutamatergic stimulation of luteinising hormone release in Kiss1 knockout rats. J. Neuroendocrinol. 27, 187-197. doi: 10.1111/jne.12257

Unuane, D., Tournaye, H., Velkeniers, B., and Poppe, K. (2011). Endocrine disorders \& female infertility. Best Pract. Res. Clin. Endocrinol. Metab. 25, 861-873. doi: 10.1016/j.beem.2011.08.001

Wang, X. N., and Greenwald, G. S. (1993). Hypophysectomy of the cyclic mouse. II. Effects of follicle-stimulating hormone (FSH) and luteinizing hormone on folliculogenesis, FSH and human chorionic gonadotropin receptors, and steroidogenesis. Biol. Reprod. 48, 595-605. doi: 10.1095/biolreprod48.3.595

Weick, R. F., and Noh, K. A. (1984). Inhibitory effects of estrogen and progesterone on several parameters of pulsatile LH release in the ovariectomized rat. Neuroendocrinology 38, 351-356. doi: 10.1159/000123916

Wildt, L., Häusler, A., Marshall, G., Hutchison, J. S., Plant, T. M., Belchetz, P. E., et al. (1981). Frequency and amplitude of gonadotropin-releasing hormone stimulation and gonadotropin secretion in the rhesus monkey. Endocrinology 109, 376-385. doi: 10.1210/endo-109-2-376

Yip, S. H., Boehm, U., Herbison, A. E., and Campbell, R. E. (2015). Conditional viral tract tracing delineates the projections of the distinct kisspeptin neuron populations to Gonadotropin-Releasing Hormone ( $\mathrm{GnRH}$ ) neurons in the mouse. Endocrinology 156, 2582-2594. doi: 10.1210/en. 2015-1131

Conflict of Interest Statement: The authors declare that the research was conducted in the absence of any commercial or financial relationships that could be construed as a potential conflict of interest.

Copyright (c) 2016 Göngrich, García-González, Le Magueresse, Roth, Watanabe, Burks, Grinevich and Monyer. This is an open-access article distributed under the terms of the Creative Commons Attribution License (CC BY). The use, distribution or reproduction in other forums is permitted, provided the original author (s) or licensor are credited and that the original publication in this journal is cited, in accordance with accepted academic practice. No use, distribution or reproduction is permitted which does not comply with these terms. 